\title{
Learn From Home in The COVID-19 Pandemic:
} The New Difficulties

\author{
Putu Indra Christiawan ${ }^{1, *}$, Ida Bagus Made Astawa ${ }^{1}$, I Gede Astra Wesnawa ${ }^{1}$ \\ ${ }^{1}$ Geography Department, Universitas Pendidikan Ganesha, Bali, Indonesia \\ *Corresponding author. Email: indra.christiawan@undiksha.ac.
}

\begin{abstract}
During the COVID-19 pandemic, learning from home was a new strategy implemented to ensure the teaching and learning process continued. Even though e-learning is accessible in universities, many academicians are not ready to implement it. This study aims to analyze the difficulties students face in implementing learning strategies from home during these social and physical restrictions. Through a basic qualitative research design, data collected through online questionnaire distribution techniques to 100 respondents was taken as a purposive random sample and analyzed with analytic induction techniques. The results showed that in implementing e-learning during the pandemic, students experienced two significant difficulties. First is the difficulty that comes from the pandemic, i.e., the lack of funds to buy internet data, unstable internet network, having the responsibility to help parents, and no internet access. Second are personal difficulties caused by physical and psychological fatigue, slow devices response to run e-learning applications, and difficulty understanding the material. This condition indicates that students face high pressure in implementing e-learning during the COVID-19 pandemic.
\end{abstract}

Keywords: Learn from home, covid-19, online learning, student perspectives, higher education, learning difficulties

\section{INTRODUCTION}

The policies are taken by many countries, including Indonesia, to carry out lockdowns, physical distancing, selfisolation, and travel restrictions are efforts to break the chain of spreading Coronavirus Disease 2019 (COVID-19). The coronavirus's spread initially had a profound impact on the economic and social world, but now the impact is also being felt by the world of education (Purwanto et al., 2020). The COVID-19 pandemic has influenced all education systems from the playgroup, elementary school, high school to university level institutions. UNESCO estimates that nearly 900 million students have been affected by educational institutions' closure due to the COVID-19 pandemic (Nicola et al., 2020). Closing educational institutions due to the COVID19 pandemic has a significant impact on the learning and learning process.

Adjustments to educational policies during the COVID-19 pandemic affect policies in universities. Face-to-face lectures become online learning. Online learning used is learning in a network-assisted by information and communication technology. Online learning is a learning process that utilizes information technology, utilizing the internet as a method of delivery, interaction, and facilitation. Online learning is learning that utilizes the advantages of computers as a medium for instructors and students to communicate efficiently. Online learning provides opportunities for students to ask questions or express opinions indirectly. Online learning makes use of independent teaching materials that anyone can access anytime via internet technology. Online learning will facilitate the improvement and storage of lecture materials so that updating electronic teaching materials is easy. There is also a learning system design that each participant can learn and known (Saputro et al., 2017). The online learning system is also implemented at the Universitas Pendidikan Ganesha (UNDIKSHA).

The application of online learning is quite sudden, causing lecturers, especially those who have never carried out online learning, to have difficulty preparing materials and materials. Utami et al. (2020) suggests that even though online learning infrastructure is available, only $32 \%$ of UNDIKSHA lecturers are implementing online learning, and most of them still apply conventional learning. This fact indicates that many lecturers and students do not have experience in the application of online learning. In other words, some campus stakeholders who are not familiar or have never used online learning face difficulties in its implementation-especially learning difficulties for students.

Learning difficulties are disorders in individuals who experience difficulties in carrying out an active learning 
process. Folley (2010) believes that learning difficulties are not related to one's intelligence, but are related to one's difficulty in mastering learning skills. Several input factors cause learning difficulties. Mulyati (2010) states that learning difficulties have a broad and deep understanding because they involve: (1) learning disorder, (2) there are symptoms of learning dysfunction (learning dysfunction), (3) students who have the level of intellectual potential is classified as not usual (underachiever), and (4) students are slow in carrying out the learning process (slow learner). A student can be seen or suspected of having learning difficulties if he/she is unable to follow the learning well (Firmansyah, 2017) or shows a failure to achieve learning goals (Wasito \& Kurniawan, 2018).

Sukaswanto (2013) identifies four factors that cause learning difficulties. The first factor is the material or thing that must be studied. The materials or things that must be studied determine how the learning process occurs, and how the results can be expected. Besides, the level of difficulty and complexity of the material that must be studied also has a significant influence on the learning difficulties faced. The second factor is environmental factors. Environmental factors can be grouped into two groups, namely the natural environment and the social environment. The natural environment, such as temperature, humidity, can affect learning processes and outcomes. The social environment, which has a human form and its representation and other forms, directly affect the learning process. Other social environments, such as the sound of factory machines, the bustle of traffic, also affect learning difficulties. The third factor is the instrumental factor. Instrumental factors are factor whose existence and use are designed according to the expected learning outcomes. These factors serve as a means to achieve the planned learning objectives. This factor can be in the form of hardware or software. The last is the student's condition factor. Individual student conditions that affect learning difficulties can be divided into physiological conditions.

This research focuses on the difficulties faced by UNDIKSHA students in implementing online learning. Many studies have examined difficulties in online learning, and most of them only examine lecturers' perspectives (Idris, 2017; Wasito \& Kurniawan, 2018; Guri-Rosenblit, 2018; Lawrence et al., 2019). There are still few who examine learning difficulties from the students' perspective, especially during the COVID-19 pandemic. Therefore, this study aims to analyze various learning difficulties experienced by students in learning from home, including evaluating the factors that cause these learning difficulties. This study is needed to improve and perfect the implementation of online learning during a pandemic and create sustainable learning from home models and strategies in the future.

\section{METHOD}

\section{1. Research Design}

This research is included in the case study research. The research location is focused on the Faculty of Law and Social
Sciences, Universitas Pendidikan Ganesha (UNDIKSHA). The population of this research is even semester students, amounting to 100 students. This study uses a qualitative approach that emphasizes in-depth observations about learning difficulties during the COVID-19 pandemic and the factors that led to student learning difficulties in online learning. A qualitative approach is used as an approach in this research because it is useful for understanding the object's real conditions.

\subsection{Data Analysis}

In qualitative research, a purposive sampling technique is a method used to achieve particular research objectives. The instrument used to collect data was a questionnaire distributed online. Analysis and interpretation of data is the most critical part of qualitative research (Creswell, 2012). Thematic data analysis guidelines are the guidelines used in this study because they are considered the most appropriate for any research that seeks to explore several interpretations. In thematic analysis, all possible interpretations are possible. The rationale for choosing thematic analysis is that "a rigorous thematic approach can result in an in-depth analysis that answers research questions.

\section{RESULT AND DISCUSSION}

\section{1. Difficulties in the Learning from Home}

Learning difficulties are triggers for failure to achieve learning goals. The forms of difficulties faced by students in taking online learning during the pandemic are very diverse. Various difficulties experienced by students in learning from home are shown in Table 1 .

Table 1. Difficulty of learning from home in the pandemic period

\begin{tabular}{|l|c|}
\hline Difficulties & $\begin{array}{l}\text { Percentage } \\
\text { (\%) }\end{array}$ \\
\hline A. Pandemic aspects & 37 \\
\hline Insufficient internet data & 33 \\
\hline Unstable internet network & 26 \\
\hline Take full lectures & 4 \\
\hline No internet access & 100 \\
\hline Total & \\
\hline B. Personal aspects & 38 \\
\hline Difficult to concentrate & 30 \\
\hline Non-standard device & 18 \\
\hline Physical exhaustion & 14 \\
\hline Difficult to understand the material & 100 \\
\hline Total & \\
\hline
\end{tabular}

Table 1 shows the two main difficulties faced by students when participating in learning during the COVID-19 pandemic. The first learning difficulty comes from the pandemic aspect, and the second comes from the student's personality. 
Learning difficulties faced by students from a pandemic perspective are as follows:

(a) Lack of internet data is the most significant difficulty students experience during the learn from the home process. As many as $37 \%$ of students stated that their internet data was insufficient to follow the entire online learning process. The number of applications used by lecturers and downloading and uploading material consumes many internet data.

(b) An unstable internet network is a second biggest difficulty faced by students. As many as $33 \%$ of students stated that they had difficulty participating in learning, especially when using web conferencing. Many lecturers' explanations were disconnected due to unstable connections.

(c) There are $26 \%$ of students who have difficulty following learning from home according to schedule because they have to help parents at home. Responsibility as family members obliges them to prioritize the work of helping parents before attending learning.

(d) The last difficulty, at least but essential, is that there are $4 \%$ of students whose locations of residence do not have internet access. They cannot follow the normal online learning process.

The four difficulties faced by the students were new difficulties in implementing learn from home. Almarabeh \& Mohammad (2013) and Bajpai (2015), which examined the implementation of online learning in remote areas, found that even though students' homes did not have internet access, there were one or two locations they could visit to get internet access. Meanwhile, during the COVID-19 pandemic, those who did not have internet access in their home environment had limitations to visit public places to get internet access.

Other learning difficulties faced by students in the learning from home process or online learning stem from the following personal aspects:

(a) Most students or $38 \%$ stated that they had difficulty concentrating. A large number of assignments and bills make it difficult for them to focus on one subject or assignment.

(b) Non-standard equipment ownership (hardware and software) is the second most significant difficulty for students in the following learning from home. As many as $22 \%$ of students have devices that do not support some learning applications.

(c) The dense lecture schedule makes students experience physical fatigue. As many as $18 \%$ of students admitted to being tired in participating in online learning, especially eyestrain, when paying attention to screens on their devices.

(d) The least difficulty experienced by students is in understanding the material. There are $14 \%$ of students who have difficulty understanding the material, especially in understanding lecturers' explanations, which are considered too fast.

These four difficulties are different from various studies, which view that the only difficulty in implementing online learning only includes difficulties in the academic realm (Al-Samarraie et al., 2017). This study reveals the many difficulties students face in implementing learning from home, and most of them do not come from academic issues.

\subsection{Factors Causing Difficulty Learning from Home}

The application of online learning during the COVID-19 pandemic has created various difficulties. Some of them are new difficulties that have never been experienced before. There are unusual causative factors behind these difficulties. Identify the factors that cause learning difficulties from home, as shown in Table 2.

Table 2. Causes of learning difficulties in the pandemic period

\begin{tabular}{|l|c|}
\hline Factors & $\begin{array}{l}\text { Percentage } \\
(\%)\end{array}$ \\
\hline A. Pandemic factors & 47 \\
\hline There are no funds to buy intemet data & 34 \\
\hline Have to share intermet access & 15 \\
\hline Must help parents eam money & 4 \\
\hline Residing in a remote area & 100 \\
\hline Total & 46 \\
\hline B. Personal factors & 28 \\
\hline Less conducive learning environment conditions & 14 \\
\hline Less used to using e-learning applications & 12 \\
\hline Inadequate learning resources & 100 \\
\hline $\begin{array}{l}\text { Lack of time to work on assignments/answer } \\
\text { questions }\end{array}$ & \\
\hline Total & \\
\hline
\end{tabular}

Table 2 shows two factors causing learning difficulties during the COVID-19 pandemic. The first causal factor is derived from a pandemic factor, and the second is sourced from student personal factors.

The causes of student learning difficulties due to pandemic factors are as follows:

1) The COVID-19 pandemic has resulted in a slowdown in the economy. The direct impact experienced by the community is a decrease in income. Declining parental income has resulted in $47 \%$ of students being unable to afford internet data so that the internet data they have is not sufficient to meet the needs of the online learning.

2) Not only students who learn from home, but many parents also work from home. This results in a high need for internet in the household and makes $34 \%$ of students have to share internet access with their parents and siblings. Therefore, they often experience internet network instability.

3) In addition to reducing parents' income, the pandemic has also resulted in many workers losing their jobs. As much as $11 \%$ of students must help their parents to make a living. 
4) The last factor is the location where students live in the interior. As many as $4 \%$ of students live in areas that are not connected to the internet. Although they tried to find a location with internet access, they were hindered by the rules for large gatherings.

The factors that cause learning difficulties caused by student personalities are:

1) Most students (46\%) state that the main learning difficulties are caused by the conditions of the learning environment that are less comfortable and conducive. The unavailability of a particular study room and a large number of family members at home resulted in them being unable to concentrate on learning from home.

2) The second personal factor is that some students (28\%) say that they are not accustomed to using e-learning applications. During a pandemic, many e-learning applications are available, and each lecturer uses a different application. Many of these applications are not supported by the devices they have.

3) The third personal factor is the lack of learning resources they have. As much as $14 \%$ of students admitted that they had no learning resources except lecturers' presentation material. Therefore, they have difficulty in understanding learning material in a holistic way.

4) The final factor is the lack of time allotted for work. A small proportion of students $(12 \%)$ stated that the lecturer's time duration to answer questions or do assignments was concise. This condition makes them experience high physical fatigue.

The factors were causing learning difficulties during the pandemic that have been described contrast from those that cause learning difficulties online commonly. In a previous study in normal times, the main factors that cause learning difficulties are students' low initial knowledge, low self-esteem (El-Seoud et al., 2014), and weak communication skills (Gon \& Rawekar, 2017). However, the same causal factors were found in previous studies, namely the lack of students' ability to focus for long periods and the lack of learning resources they had (Folley, 2010; Jara \& Mellar, 2010). The factors that cause learning difficulties, both from pandemic and personal factors, have the same implications for the low effectiveness of online learning during a pandemic. The difficulties caused by the COVID-19 pandemic and exacerbated by students' personal conditions created new difficulties in the learning from home.

\section{CONCLUSION}

Learning from home in the form of online learning in anticipation of the COVID-19 pandemic has not led students to study optimally. There are many difficulties faced by students in implementing learn from home, especially the limited internet data to participate in online learning, and also the difficulty of concentrating on online learning. It is noted that the economic downturn and the less conducive learning environment cause these difficulties. Visionary online learning concepts and strategies are needed to overcome the learning difficulties that have just arisen due to the COVID-19 pandemic.

\section{REFERENCES}

[1] H. Al-Samarraie, B. K.Teng, A. I. Alzahrani, \& N. Alalwan, E-learning continuance satisfaction in higher education: a unified perspective from instructors and students. Studies in Higher Education. 2017.

[2] T. lmarabeh, \& H. Mohammad, E-learning in the jordanian higher education system: strengths, weakness, opportunities, and threats. Journal of American Science, 9(3), 281-287, 2013.

[3] S. Bajpai, Proposed framework of e-learning in remote areas of uttarakhand: in perspective with mobile communication. International Journal of Innovative Science, Engineering \& Technology, 2(6), 693-697, 2015.

[4] J. W. Creswell, Research design pendekatan kualitatif, kuantitatif dan mixed. Pustaka Pelajar. 2012.

[5] A. Eftychia, Home learning activities and children's learning outcomes: a review of recent evidence. European Journal of Education Studies, 6(1), 100-159, 2019.

[6] M. S. A.El-Seoud, I. A. T. Taj-Eddin, \& N. Seddiek, Elearning and students' motivation: a research study on the effect of e-learning on higher education. IJET, 9(4), 20 26, 2014.

[7] M. A. Firmansyah, Analisis hambatan belajar mahasiswa pada mata kuliah statistika. JPPM, 10(2), 115-127, 2017.

[8] D. Folley, The lecture is dead long live the e-lecture. Electronic Journal of E-Learning, 8(2), 93-100, 2010.

[9] S. Gon, \& A. Rawekar, Effectivity of e-learning through Whatsapp as a teaching learning tool. MVP Journal of Medical Sciences, 4(1), 19-25, 2017.

[10] S. Guri-Rosenblit, E-teaching in higher education: an essential prerequisite for e-learning. Journal New Approaches In Educational Research, 7(2), 93-97, 2018.

[11] R. Idris, Mengatasi kesulitan belajar dengan pendekatan psikologi kognitif. Lentera Pendidikan: Jurnal Ilmu Tarbiyah Dan Keguruan, 12(2), 152-172, 2017.

[12] M. Jara, \& H. Mellar, Quality enhancement for e-learning courses: the role of student feedback. Computers \& Education, 54, 709-714, 2010.

[13] R. Lawrence, L. F. Ching, \& H. Abdullah, Strengths and 
weaknesses of education $4.0 \mathrm{~m}$ the higher education institution. International Journal of Innovative Technology and Exploring Engineering (IJITEE), 9(23), 511-519, 2019.

[14] Mulyati, Diagnosa kesulitan belajar. IKIP PGRI Semarang Press. 2010.

[15] M. Nicola, Z. 1safi, C. Sohrabi, A. Kerwan, A. Al-Jabir, \& C. Iosifidis, The socioeconomic implications of The Coronavirus And COVID-19 Pandemic: A Review. International Journal of Surgery, 1-24, 2020.

[16] A. Purwanto, R. Pramono, M. Asbari, P. B. Santoso, L. M. Wijayanti, C. C. Yun, \& R. S. Putri, Studi eksploratif dampak pandemi COVID-19 terhadap proses pembelajaran online di Sekolah Dasar. Edupsycouns Journal (Journal Of Education, Psychology, And Counseling), 2(1), 1-12, 2020.

[17] F. B. Saputro, M. Somantri, \& A. Nugroho, Pengembangan sistem kuliah online Universitas Diponegoro untuk antar muka mahasiswa pada perangkat bergerak berbasis android. Transmisi, 19(1), 15-21, 2017.

[18] Sukaswanto. Diagnosis kesulitan belajar mahasiswa pada mata kuliah statika dan kekuatan material. Jurnal Pendidikan Teknologi Dan Kejuruan, 21(4), 314-324, 2013.
[19] N. W. Utami, I. K. R. Arthana, \& I. G. M. Darmawiguna, Usability evaluation in e-learning of Universitas Pendidikan Ganesha using usability testing method (in Bahasa). Jurnal Nasional Pendidikan Teknik Informatika : JANAPATI, 9(1), 107-118, 2020.

[20] N. Wasito, \& F. A. Kurniawan, Analisis Penyebab Kesulitan belajar mahasiswa dalam pembelajaran konstruktivistik mata kuliah aljabar linier. Jurnal Pendidikan Matematika Indonesia, 3(2), 47-51, 2018. 